IZA DP No. 9044

Do Schools Discriminate Against Homosexual Parents?

Evidence from an Internet Field Experiment

Luis Diaz-Serrano

Enric Meix-Llop

May 2015 


\title{
Do Schools Discriminate Against Homosexual Parents? \\ Evidence from an Internet Field Experiment
}

\author{
Luis Diaz-Serrano \\ CREIP, Universitat Rovira i Virgili \\ and IZA \\ Enric Meix-Llop \\ CREIP, Universitat Rovira i Virgili \\ Discussion Paper No. 9044 \\ May 2015
}

IZA

P.O. Box 7240

53072 Bonn

Germany

Phone: +49-228-3894-0

Fax: +49-228-3894-180

E-mail: iza@iza.org

Any opinions expressed here are those of the author(s) and not those of IZA. Research published in this series may include views on policy, but the institute itself takes no institutional policy positions. The IZA research network is committed to the IZA Guiding Principles of Research Integrity.

The Institute for the Study of Labor (IZA) in Bonn is a local and virtual international research center and a place of communication between science, politics and business. IZA is an independent nonprofit organization supported by Deutsche Post Foundation. The center is associated with the University of Bonn and offers a stimulating research environment through its international network, workshops and conferences, data service, project support, research visits and doctoral program. IZA engages in (i) original and internationally competitive research in all fields of labor economics, (ii) development of policy concepts, and (iii) dissemination of research results and concepts to the interested public.

IZA Discussion Papers often represent preliminary work and are circulated to encourage discussion. Citation of such a paper should account for its provisional character. A revised version may be available directly from the author. 


\section{ABSTRACT}

\section{Do Schools Discriminate Against Homosexual Parents? Evidence from an Internet Field Experiment ${ }^{*}$}

The recognition of homosexual rights is a controversial issue in many countries. Spain was the third country in the world (after Netherlands and Belgium) to introduce a law recognizing homosexual marriage and adoption of children. In this paper, we examine for the first time whether schools are more hesitant to give feedback to homosexual parents during children's pre-registration period in Spain. In order to do that, we designed an internet field experiment to be conducted in schools. We created three types of fictitious couples; one heterosexual, one male homosexual and one female homosexual, and send emails to schools making sexual orientation explicit. Our results show that men homosexual couples had a significant lower probability to receive and answer than heterosexual couples (22.5 percentage points less). No statistically significant differences in the response rate were found between female homosexual and heterosexual couples. This result suggests that male homosexual couples might be penalized because of the lack of a maternal figure.

JEL Classification: H41, I20, K36

Keywords: discrimination, field experiment, schools, homosexual rights

Corresponding author:

Luis Diaz-Serrano

Department of Economics

Universitat Rovira i Virgili

Av. Universitat 1

43204 Reus

Spain

E-mail: luis.diaz@urv.cat

\footnotetext{
* The authors would like to acknowledge the financial support of the Spanish Ministry of Economy and Innovation (grant number ECO2010-20829). Comments from the participants in the Workshop on Empirical Research in the Economics of Education (https://sites.google.com/site/qureeconomics/), the seminar series at the Department of Economics (Universitat Rorvira i Virgili) and the "Forum de Recerca" at the Department of Political Science and Sociology (Universitat Pompeu Fabra) are also greatly acknowledged.
} 


\section{1- Introduction}

Although the literature analyzing discrimination against women and minorities regarding many outcomes is quite abundant, studies analyzing discrimination against homosexuals are still very scarce. The few existing studies regarding this issue document the existence of sexual orientation discrimination. Given the recent implementation of policies in favor of homosexual rights and the normalization of homosexual families in many developed countries, we find this issue is of special interest. Despite its relevance, we think that discrimination against homosexuals is undoubtedly under researched. The main reason of this gap is attributable to the lack of reliable register and survey data for identifying sexual orientation.

Some studies resorting to survey and register data in different countries report statistically significant earnings differentials across individuals/households according to their sexual orientation. However, because of the identification problems of individuals' sexual orientation mentioned above, internet field experiments seem to be a more reliable method to test for discrimination against homosexuals. The experiments focused on the labor and the rental housing market. Studies regarding the labor market found that compared to heterosexuals applicants with similar characteristics, gays and lesbians were less likely to be invited for a job interview. In the rental housing market, this type of discrimination was observed only for gay applicants.

In this paper, we test whether private schools are more hesitant to interact with homosexual than with heterosexual parents. The experiment was conducted in the region of Catalonia (Spain) during the pre-registration period in schools. Preregistration is compulsory and has to occur before schools, either public or private, 
decide on children's admittance. However, parents can only choose among private schools, since in public schools the assignment of children to schools depends on the geographical proximity of the household address to the school. This is why our experiment only considers private schools

The main motivation of this paper was the following new in the media: On January $29^{\text {th }} 2014$, the main national Spanish newspaper El País published the following news story: "The principal of a school was accused in court of turning down the application by a gay couple for their son". This happened in a private school in Seville. The principal of the school turned down the application, alleging that there were no vacancies. However, the parents of the child knew that this was not true and brought the case to the Court of Justice. Of course, one case does not in itself infer that most Spanish schools discriminate against homosexual parents. However, one question emerges from this case of discrimination: Is this discriminatory behaviour from this school against this homosexual couple a generalized problem or this can only be taken as anecdotal evidence? This is the question we want to answer in this paper. In order to do that, we designed an internet field experiment with schools in the region of Catalonia (Spain). As far as we are aware, this is first paper analyzing whether schools discriminate against homosexual parents. We focus on this type of discrimination not only because it affects homosexual parents, but also their children's education, which is one of their most fundamental rights.

Our internet field experiment involved the creation of three different fictitious profiles (heterosexual, male homosexual and female homosexual couples) and sending emails to schools during children's pre-registration period. We decided to consider also female homosexual couples in order to control for the gender of the homosexual 
parents. We think that in some cases schools or school principals might penalize not only the sexual orientation of the parents, but also the lack of a maternal figure. In these emails our fictitious couples showed interest in the school and made a request for an interview and a visit. In the emails their sexual orientation was made explicit. After processing all the email responses from schools, we created a database that allowed us to test whether schools were more hesitant to give feedback to homosexual parents than their heterosexual counterparts. Our results indicate that male homosexual parents were 22.5 percentage points less likely, in respect to heterosexual couples, to receive an answer from the schools. Female homosexual couples were also less likely to receive an answer from the schools (almost 4 percentage points less). However, this difference was not statistically significant. These findings are consistent with previous evidence based on internet field experiments testing for discrimination against homosexuals.

The paper is structured as follows. In section 2 we describe the institutional setting. In section 3 we provide an overview of the existing literature regarding homosexual discrimination. The experimental design is described in section 4 . Section 5 reports the empirical results. Finally, section 6 summarizes and concludes.

\section{Homosexual families and institutional settings}

The recognition of homosexual rights is a controversial issue in many countries. In 2001, The Netherlands was the first country in the world to recognize same-sex couples marriage. Since then, this right has also been recognized in other countries. ${ }^{1}$ More

\footnotetext{
${ }^{1}$ South-Africa, Portugal, Spain, Iceland, Argentina, Denmark, Uruguay, New Zealand, France and Brazil allow homosexual marriages while in United States and Mexico it is only allowed in some states.
} 
recently, other countries granted homosexual couples the right to adopt children. ${ }^{2}$ Both measures aim to recognize and normalize homosexual family structures. Despite these advances, there are some countries where homosexuality is still persecuted and punished, in some cases by the death penalty ${ }^{3}$.

Spain was the third country in the world (after the Netherlands and Belgium) to introduce a law recognizing marriage between same-sex couples. It was promoted by $\mathrm{PSOE}^{4}$ (the left-wing party in office) and became effective on the 3rd July 2005. It faced opposition from the Catholic Church and the PP (the main right-wing party), who claimed that this law was against the Spanish Constitution and brought this case to the Spanish Constitutional Court. However, in 2012 their appeal was declined. In the same law homosexual couples were also granted the same rights to adopt children as heterosexual couples. ${ }^{5}$ Since then, with the support of the main right-wing party (PP), the Catholic Church and Catholic pro-family conservative associations have organized several demonstrations against the right of homosexual couples to adopt children.

In this context, one question arises: Is the polarization reflected in Parliament also reflected in society and institutions? The European Value Study positions Spain in a middle position regarding homosexual acceptance compared to other EU15 countries. ${ }^{6}$ About $20 \%$ of the Spaniards interviewed in this study declared that they do not like the idea of having homosexuals as neighbors (Figure 1). Portugal, Austria, Italy, Ireland,

\footnotetext{
${ }^{2}$ Andorra, Argentina, Spain, Belgium, Brazil, Canada, Denmark, Norway, South-Africa, Sweden, UK, Uruguay, Finland, Germany, Israel and Slovenia allow homosexuals to adopt children, while in Australia, Mexico and the United States it is only allowed in some states.

${ }^{3}$ Countries where homosexuality is punished with the death penalty are Libya, Sudan, Mauritania, Nigeria, Somaliland, Saudi Arabia, Yemen, Afghanistan, Iran and the Maldives.

${ }^{4}$ The House of Representatives approved the law on a first round by 183 votes against 136 . In the Senate the law was rejected by 131 votes to 119 . In Congress, the veto was lifted and the law finally passed by 187 votes to 147 .

${ }^{5}$ Law $13 / 2005$, article 44.

${ }^{6}$ This study shows that the ex-communist European countries are by far the most homophobic.
} 
Greece and Germany have exhibited higher levels of intolerance, with the Nordic countries, Netherlands, France and Belgium emerging as the most tolerant.

However, when we analyze the question of whether individuals agree with the adoption of children by homosexual couples, the results are more different across the board. Some countries that reported more tolerance of having homosexuals as neighbors now exhibit a similar or even more negative position than Spaniards towards the idea of homosexuals adopting children (Sweden, France, Finland, Denmark and Belgium). This leaves Spain as one of the most tolerant EU countries regarding this issue (Figure 2).

[Insert Figure 1, around here]

[Insert Figure 2, around here]

\section{Literature Review}

Although economic literature regarding sexual orientation discrimination is scarce, the existence of discrimination against homosexuals is documented in some countries. The majority of these studies are focused on differences between homosexuals and heterosexuals in the labor market. These analyses generally resort to surveys and register data and in to a lesser extent to internet field experiments. More recently, internet field experiments have also been used to detect discrimination against homosexuals in the rental housing market. As far as we are aware, there is no previous

study that explores discrimination against homosexual parents on the specific issue of 
their children being admitted to schools, or in any other more general issue regarding the school environment.

Using U.S. survey data, Badgett (1995) found that male homosexuals and bisexuals workers earn between $11 \%$ and $27 \%$ less than their heterosexual counterparts. However, Allegretto and Arthur (2001) found that this wage differential can be attributed in part to a penalty for being unmarried. They found that unmarried male homosexuals earn $15 \%$ less than similarly qualified married heterosexuals but only $2.4 \%$ less than unmarried male heterosexuals.

Arabsheibani et al $(2004,2005)$ conducted the first study in the UK analyzing earnings discrimination against homosexuals. They found that male homosexuals had lower earnings than similarly qualified heterosexuals while female homosexuals earned about the same and in some cases more than heterosexuals. This implies that the wage gender gap is bigger among heterosexual workers than among homosexuals. Plug and Berkhout (2004) examined whether such differences in incomes in the Netherlands occur at the beginning of working careers or whether it is a more long term phenomenon. They found that wage differentials due to sexual orientation are lower in entry level jobs; $3 \%$ less for male homosexuals and $4 \%$ more for female homosexuals compared to similarly qualified heterosexual workers.

Laurent and Mihoubi (2012) found that male homosexuals had about 6.5\% lower earnings than heterosexual men. However, using German household data Humpert (2012) found the opposite. He estimated that the household income of male homosexual households was between $9 \%$ and $15 \%$ higher than that of heterosexual households, while no differences were found between female homosexual households and 
heterosexual households. Plug and Berkhout (2008) observed that gays/bisexuals earned about 3-4 percent less than male heterosexual workers. However, they point out that this result is driven by selection and not by discrimination. More recently, using Australian data, Plug et al. (2014) found evidence that gay and lesbian workers shied away from prejudiced occupations, which supports the prejudice based theories of employer and employee discrimination against gay and lesbian workers.

The results of labor market outcomes based on survey and register data have limitations in order to detect discrimination against homosexuals. First, sexual orientation is not generally observable or declared. This might not be known by other co-workers or employers. Therefore, any potentially discriminatory attitude towards them cannot be observed. Secondly although survey and register data often asks individuals to report if they have had any same-sex sexual relations during their life, this might not give an accurate identification of homosexuality. With internet field experiments it is possible to overcome these identification problems. Using this approach we can create situations in which the individuals are interacting with fictitious homosexual individuals who clearly reveal their sexual orientation. Existing internet field experiments intended at detecting discrimination against homosexuals are basically focused on labor and housing market outcomes. Despite the literature being scarce, all the studies report one unequivocal finding: male homosexuals are discriminated against in the labor and the rental housing markets, while in the case of female homosexuals the evidence of discrimination remains inconclusive.

Ahmed et al. (2008b) carried out a field experiment in Sweden to analyze whether homosexual couples showing interest by email in renting a flat were less likely to receive feed-back from private landlords than heterosexual couples. They found that 
male homosexual couples had a lower response rate from landlords than heterosexuals. However, Ahmed et al. (2008b) found no different treatment by landlords between female homosexual couples and heterosexuals.

Regarding the labor market, several internet field experiments aimed at detecting sexual orientation discrimination in the hiring process. These studies report discrimination against both male and female homosexuals. Adam (1981) found evidence of discrimination against male homosexuals applying for articling positions in Ontario law firms. Weichselbaumer (2003) observed that in Germany female homosexuals received less interview requests than female heterosexuals with the same skills. Tilcsik (2011) conducted the first large-scale audit study in the United States regarding sexual orientation discrimination. Fictitious résumés were sent to job postings in different states. In some résumés the individual homosexual condition was randomly signaled by mentioning that the candidate had experience in gay campus organizations. The author found discrimination against those who revealed their homosexuality. Ahmed et al. (2013) found that sexual orientation discrimination exists in the Swedish labor market. They observed that the gay male applicant was discriminated against in typical male-dominated occupations, whereas the lesbian applicant was discriminated against in typical female-dominated occupations.

\section{Experimental design}

The experiment was conducted in March 2013 in Catalonia (Spain), during the primary school pre-registration period. We obtained the corporate mail of all Catalan schools from the Catalan regional educational authority. In our experiment we only consider 
private schools, ${ }^{7}$ keeping public schools out of the study. We proceed like this because the admission of children in public schools is not discretionary and children residing in a given district are automatically assigned to the closest public school to their home address in that district. This leaves us with a total number of 610 schools.

Our experiment consists of contacting schools by email and requesting an interview or a visit to the school. We resort to an internet field experiment because we are interested in studying the non-influenced behavior of the participants, which is only possible if participants do not know ex-ante that they are participating in the study. This methodology also allows us not only to reach all the schools with a remarkably low level of effort and time, but also because it makes feedback with schools easier.

We created three fictitious couples; one heterosexual, one male homosexual and one female homosexual. Since the experiment was conducted on the internet we just needed to create an e-mail address for each type of couple where schools could respond, and a name for the fictitious applicants and their respective daughters. We choose a daughter instead of randomly assigning a son or a daughter to minimize experiment costs and also because of the inexistence of schools that segregate by gender. We also think that there is no reason to think that schools could change their behavior depending on the gender of the children. Choosing a name for the corresponding applicants was an important part of this field experiment. In order to avoid any undesirable origin bias, we randomly assigned a common Spanish name to each couple and their corresponding daughter ${ }^{8}$. These are typical Spanish names, which are also gender unique. The next step was to create and assign an email address to each fictitious couple. We decided to

\footnotetext{
7 Among these private schools we can divide the sample into schools receiving public funding (concertadas) and schools without public funding.

${ }^{8}$ Names were randomly selected from the ten most common Spanish names, obtained from Spanish Bureau of Statistics (INE).
} 
use the same email provider (Gmail) and the three email addresses had the following structure: name.surname.number@gmail.com.

In order to test both male and female sexual orientation discrimination, each school received two e-mails; one from a heterosexual couple and the other from a gay or lesbian couple. In order to avoid any bias, emails from gay or lesbian couples accompanying the emails from the heterosexual couples where assigned randomly to half of the schools. Although proceeding like this we lose half of the sample for each type of homosexual couple, we gain experimental credibility and stringency. We think that schools might find suspicious receiving the three emails (gay-lesbian-hetero). The order in which each e-mail was sent (heterosexual-homosexual or homosexualheterosexual) was also randomized. The emails were sent to each school with three days of difference.

We designed templates of the three emails to be sent. We generated three different emails where the sexual orientation of the couple was made explicit. Thus, all emails had the following structure: a heading with a greeting by both members of the couple, a comment pointing out that the child belongs to both and where they show interest in enrolling the child in that school, a request for an appointment to have an interview and visit the school, and finally a closing statement signed by both members of the couple. Sexual orientation of the couple is made explicit by combining male/female, male/male and female/female names in the closing of the email. All three emails had a different content but were written in a way that did not reveal further information that might have an influence on the probability of response. An example is the following: 
Hello,

We are XXX and YYY and we are looking for a school for our 5 year old daughter ZZZ. She begins the first grade in the next academic year. We are considering this school as an option. Would it be possible for us to meet and visit the school?

Sincerely, $\mathrm{XXX}$ and YYY

In order to avoid gender bias, for schools receiving an e-mail from the male homosexual and heterosexual couples, both e-mails were signed first by a man. On the other hand, for schools receiving e-mails from female homosexual and heterosexual couples, both emails were signed by a woman. In order to avoid any undesired problem for schools, any invitation received was rapidly declined. When the pre-registration period concluded we processed all the responses and created a database with all the potential outcomes (response and invitations from schools), information regarding schools (private/semiprivate, laic/Catholic and city size) and information regarding the person signing the response (gender and school position).

\section{Results}

5.1. Descriptive analysis 
In Table 1 we show the distribution of replied emails. $24 \%$ of the schools that received hetero/gay paired emails did not replied to any of the two fictitious couples, whereas this percentage was of $30 \%$ for the lesbian/hetero paired email. However, $36 \%$ and $42 \%$ replied both fictitious couples in both pair of emails, respectively. The difference between the proportions of schools that replied only heterosexual couples and only male homosexual couples is of $22.3 \%$ ( $31.1 \%$ vs. $8.9 \%$ ), while this difference for the case of hetero/lesbian couples is of $3.3 \%$ (15.6\% vs. $12.3 \%)$.

[Insert table 1, around here]

Table 2 shows the distribution of responses/invitations and the test of differences in proportions for these variables between male homosexual and heterosexual couples. In order to obtain a variable "response", we do not distinguish whether the response is positive or negative. We find that those schools that received emails from heterosexual and male homosexual couples (305), seemed to be more hesitant to have feedback with male homosexuals than with heterosexual couples, $67.2 \%$ vs. $44.9 \%$. The gap of $22.3 \%$ in the response rate was statistically significant at any significance level. The results regarding invitations to parents to visit the school were quite similar. $63.9 \%$ of the heterosexual couples received an invitation, while the figure for male homosexual couples was $42.2 \%$. The gap in the invitation rate $(21.7 \%)$ was again statistically significant at any significant level. In Table 3 we repeat the same analysis but now we compare the feedback of schools with heterosexual and female homosexual couples. In this case, we did not observe statistically significant differences in neither the response 
rate nor the invitation rate, thought in both variables there was a positive gap in favour of heterosexual couples, $3.4 \%(57.87 \%$ vs. $54.4 \%)$ and $3.3 \%(55.1 \%$ vs. $51.8 \%)$, respectively.

[Insert table 2, around here]

[Insert table 3, around here]

Other variables, which will be used as independent variables in the econometric analysis, are described and summarized in table 4. For the sample of schools receiving emails from heterosexual and men homosexual couples, about $66.5 \%$ of schools are religious (Catholic) and about 96\% semi-private. The sample of schools receiving emails from heterosexual and women homosexual couples had similar characteristics. About $62.7 \%$ of schools are religious (Catholic) and $94 \%$ are semi-private. Therefore, it is worth noting that the majority of the schools in the sample are semi-private and more than a half are religious institutions. Around $28 \%$ of the schools are located in Barcelona city.

[Insert table 4, around here]

From most of the emails that were replied, we were also able to know who responded the email. This allowed us crate two variables picking up the gender and the 
administrative position in the school of the respondent (principal or secretary). In table 5 we report the distribution of gender/position of the email respondent and the test of differences in proportions for these variables between male homosexual and heterosexual couples. Among those responded emails from schools that received the hetero-gay paired emails, we do not observe statistically significant differences according to the gender and position of the respondent between emails responded to gay and hetero couples. Results regarding responses from schools that received the heterolesbian paired emails are qualitatively the same as the ones regarding the hetero-gay paired emails (see table 6).

[Insert table 5, around here]

[Insert table 6, around here]

\subsection{Econometric analysis}

In table 7 we show the results of the estimates of the probability of receiving a response (column 1 and 2) and an invitation (column 3 and 4), but now controlling for the type of school (private or semi-private), religious orientation (Catholic or lay) and the school's location (city size). To estimate the determinants of these probabilities we resorted to the probit model. In order to facilitate interpretation we reported estimated marginal effects instead of estimated coefficients. The results underline what was already established in the previous descriptive analysis. After controlling for the set of covariates regarding school characteristics, we observe that for male homosexual 
couples the probability of a response is 22.5 percentage points lower than for heterosexual couples (column 1). Results regarding the probability of receiving an invitation (column 2) are practically identical. For male homosexual couples the probability of receiving an invitation is 22 percentage points lower than for heterosexual couples. In both cases the estimated marginal effects are statistically significant at any significant level.

When we compare female homosexual with heterosexual couples, we observe that the probability of a response (column 3) and the probability of receiving and invitation (column 4) is 3.4 percentage points lower for the first than for the latter group. However, in both cases estimated marginal effects were not statistically significant. We also observed that none of the covariates picking up school characteristics (catholic/laic, private/semiprivate and city size) are statistically significant in any of the alternative models. Only three of the city size dummies have turned out to be statistically significant at 10 percent significance level (column 1 and 3), but any regular pattern can be inferred from this results. Although it is not shown in the results, we also estimated alternative models that included interactions between the homosexual status of the parents and the the characteristics of the schools. However, none of these interactions provided a statistically significant effect.

[Insert table 7, around here]

We also run a probit regression with the sample of responded emails. This analysis was intended at exploring whether respondent's gender and his/her administrative position 
(principal or secretary) was determinant in the probability of responding to gay or lesbian vs. heterosexual couples. In this regression we also control for the characteristics of the schools. As it is already shown in table 5 and 6 , we observe that neither the characteristics of the school nor the characteristics of the respondent were significant in determining this probability.

So far, our econometric results regarding how schools interact with parents according to their sexual orientation have backed up most of the previous evidence regarding discrimination against homosexual individuals in other contexts: wage differentials (e.g. Plug and Berkhout 2004; Ahmed and Hammarstedt 2010) or housing markets (e.g. Ahmed and Hammarstedt 2008a, Ahmed et al. 2008b). These studies also found evidence of discrimination against male homosexuals but not against female homosexual.

\section{Conclusions}

In this paper, we test for the first time whether schools are more hesitant to conduct feedback with homosexual than with heterosexual parents. In order to do so we resort to an internet field experiment with schools during the children's pre-registration period in Catalonia (Spain). We observe that male homosexual parents are 22.5 percentage points less likely to receive an answer from schools than heterosexual couples. However, differences in the response rate from schools between women homosexual and heterosexuals were not statistically significant. This evidence coincides with what is found in previous studies analyzing the existence of discrimination against homosexual in other fields. Of course, we cannot ensure that if we formally apply for the admission 
of the children of our fictitious homosexual parents in that schools, these applications would be turned down in the same proportion that we estimate here. However, it seems to us that the fact that schools are more hesitant to interact with gay couples than with heterosexual couples is indicative that some kind of subtle discrimination from schools or school principals against male homosexual couples might exist. However, this result, combined with the fact that we do not find significant differences between heterosexual and female homosexual couples, suggest that male homosexual couples might be penalized not only because their sexual orientation but because of the lack of a maternal figure. Still, this is a way of discriminating. 


\section{References}

Adam, B.D., 1981. Stigma and Employability: Discrimination by Sex and Sexual Orientation in the Ontario Legal Profession. The Canadian Review of Sociology and Anthropology, 18(2), 216-221.

Ahmed, A.M., Hammarstedt, M., 2008a. Detecting discrimination against homosexuals: evidence from a field experiment on the Internet. Economica 76, 588-597.

Ahmed, A. M., Andersson, L., Hammarstedt M., 2008b. Are lesbians discriminated against in the rental housing market? Evidence from a correspondence testing experiment. Journal of Housing Economics 17, 234-238.

Ahmed, A. M., Andersson, L., Hammarstedt M., 2013. Are gay men and lesbians discriminated against in the hiring process? Southern Economic Journal, 79(3): $565-585$

Allegretto, S.A., Arthur, M.M., 2001. An empirical analysis of homosexual/heterosexual male earnings differentials: unmarried or unequal? Industrial and Labor Relations Review 54, 631-646.

Arabsheibani, G., Marin, A., Wadsworth, J., 2004. In the pink. Homosexualheterosexual wage differentials in the UK. International Journal of Manpower $25,343-354$.

Arabsheibani, G., Marin, A., Wadsworth, J., 2005. Gay pay in the UK. Economica 72, 333-347.

Badgett, L., 1995. The wage effects of sexual orientation discrimination. Industrial and Labor Relations Review 48, 726-739.

Humpert, S., 2012. Somewhere over the rainbow: Sexual orientation discrimination in Germany. University of Lüneburg, Working papers series in Economics nº245. 
Laurent, T., Mihoubi, F., 2012. Sexual orientation and wage discrimination in France: The hiden side of the rainbow. Journal of Labor Research 33-4, 487-527.

Plug, E., Berkhout, P., 2004. Effects of sexual preferences on earnings in the Netherlands. Journal of Population Economics 17, 117-131.

Plug, E., Berkhout, P., 2008. Sexual orientation, disclosure and earnings, IZA DP No. 3290, Bonn, Germany.

Plug, E., D. Webbink and N. Martin, 2014. Sexual Orientation, Prejudice and Segregation. Journal of Labor Economics, forthcoming).

Tilcsik, A., 2011. Pride and Prejudice: Employment discrimination against openly gay men in the United States. American Journal of Sociology 117(2): 586-626.

Weichselbaumer, D., 2003. Sexual orientation discrimination in hiring. Labour Economics 10 629-642. 
Table 1: Distribution of responded emails

\begin{tabular}{lcc}
\hline & $\begin{array}{c}\text { Paired emails } \\
\text { Gay/Hetero }\end{array}$ & $\begin{array}{c}\text { Paired emails } \\
\text { Lesbian/Hetero }\end{array}$ \\
\hline \# of schools & 305 & 301 \\
Neither replied & 73 & 90 \\
Both replied & $23.9 \%$ & $29.9 \%$ \\
Replied only heterosexual & 110 & 127 \\
& $36.1 \%$ & $42.2 \%$ \\
Replied only homosexual & 95 & 47 \\
& $31.1 \%$ & $15.6 \%$ \\
Both replied (first email sent hetero) & 27 & 37 \\
Replied only heterosexual (first email sent hetero) & $8.9 \%$ & $12.3 \%$ \\
Replied only homosexual (first email sent hetero) & 75 & 57 \\
& $24.6 \%$ & $18.9 \%$ \\
& 24 & 15 \\
& $7.9 \%$ & $5.0 \%$ \\
\hline
\end{tabular}


Table 2: Response rates and invitations to visit the school heterosexual vs. male homosexual parents

\begin{tabular}{lccccc}
\hline Variable & $\begin{array}{c}\text { Sample } \\
\text { size }\end{array}$ & Heterosexual & $\begin{array}{c}\text { Men } \\
\text { Homosexual }\end{array}$ & Diff. & $\begin{array}{c}\mathrm{p}- \\
\text { value }\end{array}$ \\
\hline Response & 305 & $62.6 \%(191)$ & $49.5(151)$ & $13.1 \%$ & 0.0001 \\
Invitation & 305 & $59.3 \%(181)$ & $46.8(143)$ & $12,5 \%$ & 0.0002 \\
\hline
\end{tabular}

Notes: Number of e-mails within parentheses. 
Table 3: Response rates and invitations to visit the school heterosexual vs. female homosexual parents

\begin{tabular}{lccccc}
\hline Variable & $\begin{array}{c}\text { Sample } \\
\text { size }\end{array}$ & Heterosexual & $\begin{array}{c}\text { Women } \\
\text { Homosexual }\end{array}$ & Diff & $\begin{array}{c}\mathrm{p}- \\
\text { value }\end{array}$ \\
\hline Response & 301 & $57.8 \%(174)$ & $54.4 \%(164)$ & $3.4 \%$ & 0.1380 \\
Invitation & 301 & $55.1 \%(166)$ & $51.8 \%(156)$ & $3.3 \%$ & 0.1321 \\
\hline
\end{tabular}

Notes: Number of e-mails within parentheses. 
Table 4: Explanatory variables used in econometric analysis

\begin{tabular}{|c|c|c|c|c|c|}
\hline \multirow[t]{2}{*}{$\begin{array}{l}\text { Independent } \\
\text { variables }\end{array}$} & \multirow[t]{2}{*}{ Description } & \multicolumn{2}{|c|}{$\begin{array}{l}\text { Hetero and } \\
\text { Men Homo }\end{array}$} & \multicolumn{2}{|c|}{$\begin{array}{c}\text { Hetero and } \\
\text { Women Homo }\end{array}$} \\
\hline & & Mean & $\mathrm{Sd}$ & Mean & $\mathrm{Sd}$ \\
\hline Religious & $\begin{array}{l}1 \text { If the school depends on a } \\
\text { religious institution }\end{array}$ & $\begin{array}{l}0.665 \\
(203)\end{array}$ & 0.472 & $\begin{array}{l}0.627 \\
(189)\end{array}$ & 0.484 \\
\hline Non-religious & $\begin{array}{l}1 \text { If the school not depends on a } \\
\text { religious institution }\end{array}$ & $\begin{array}{l}0.334 \\
(102)\end{array}$ & 0.472 & $\begin{array}{l}0.372 \\
(112)\end{array}$ & 0.484 \\
\hline Semi-private & $\begin{array}{l}1 \text { If it is a private schools } \\
\text { receiving public funds }\end{array}$ & $\begin{array}{l}0.960 \\
(293)\end{array}$ & 0.194 & $\begin{array}{l}0.940 \\
(283)\end{array}$ & 0.237 \\
\hline Private & $\begin{array}{l}1 \text { If it is a private schools not } \\
\text { receiving public funds }\end{array}$ & $\begin{array}{c}0.039 \\
(12)\end{array}$ & 0.194 & $\begin{array}{c}0.059 \\
(18)\end{array}$ & 0.237 \\
\hline Less 10.000 & $\begin{array}{l}1 \text { if the school is located in an } \\
\text { area of less than } 10.000 \\
\text { inhabitants }\end{array}$ & $\begin{array}{c}0.111 \\
(34)\end{array}$ & 0.314 & $\begin{array}{c}0.086 \\
(26)\end{array}$ & 0.281 \\
\hline 10.000 to 50.000 & $\begin{array}{l}1 \text { if the school is located in an } \\
\text { area from } 10.000 \text { to } 50.000 \\
\text { inhabitants }\end{array}$ & $\begin{array}{c}0.232 \\
(71)\end{array}$ & 0.422 & $\begin{array}{r}0.235 \\
(71)\end{array}$ & 0.424 \\
\hline 50.000 to 100.000 & $\begin{array}{l}1 \text { if the school is located in an } \\
\text { area from } 50.000 \text { to } 100.000 \\
\text { inhabitants }\end{array}$ & $\begin{array}{c}0.134 \\
(41)\end{array}$ & 0.341 & $\begin{array}{c}0.1362 \\
(41)\end{array}$ & 0.343 \\
\hline $\begin{array}{l}\text { More than } 100.000 \\
\text { excluding } \\
\text { Barcelona }\end{array}$ & $\begin{array}{l}1 \text { if the school is located in an } \\
\text { area of more than } 100.000 \\
\text { inhabitants }\end{array}$ & $\begin{array}{c}0.242 \\
(74)\end{array}$ & 0.429 & $\begin{array}{c}0.2425 \\
(73)\end{array}$ & 0.428 \\
\hline Barcelona city & $\begin{array}{l}1 \text { if the school is located in } \\
\text { Barcelona }\end{array}$ & $\begin{array}{c}0.278 \\
(85)\end{array}$ & 0.448 & $\begin{array}{l}0.2990 \\
(90)\end{array}$ & 0.458 \\
\hline Number of schools & & & & & \\
\hline
\end{tabular}

Notes: Number of e-mails within parentheses. 
Table 5: Summary statistics for the respondent of the email (pairs hetero - gay)

\begin{tabular}{|c|c|c|c|c|c|c|}
\hline & \multicolumn{2}{|c|}{ Hetero } & \multicolumn{2}{|c|}{ Gay } & \multirow[b]{2}{*}{ Diff } & \multirow[b]{2}{*}{ t-stat } \\
\hline & Mean & std & Mean & std & & \\
\hline Secretary & $\begin{array}{r}0.278 \\
(57)\end{array}$ & 0.448 & $\begin{array}{r}0.226 \\
(31)\end{array}$ & 0.418 & 0.052 & 1.073 \\
\hline Principal & $\begin{array}{r}0.400 \\
(82)\end{array}$ & 0.490 & $\begin{array}{r}0.387 \\
(53)\end{array}$ & 0.487 & 0.013 & 0.244 \\
\hline Unknown position & $\begin{array}{r}0.322 \\
(66)\end{array}$ & 0.467 & $\begin{array}{r}0.387 \\
(53)\end{array}$ & 0.487 & -0.065 & -1.235 \\
\hline Male & $\begin{array}{r}0.176 \\
(36)\end{array}$ & 0.380 & $\begin{array}{r}0.139 \\
(19)\end{array}$ & 0.346 & 0.037 & 0.911 \\
\hline Female & $\begin{array}{l}0.532 \\
(109)\end{array}$ & 0.499 & $\begin{array}{r}0.547 \\
(75)\end{array}$ & 0.498 & -0.016 & -0.286 \\
\hline Unknown gender & $\begin{array}{r}0.293 \\
(60)\end{array}$ & 0.455 & $\begin{array}{r}0.314 \\
(43)\end{array}$ & 0.464 & -0.021 & -0.418 \\
\hline $\mathrm{N}$ & 205 & & 137 & & & \\
\hline
\end{tabular}

Notes: Number of e-mails within parentheses. 
Table 6: Summary statistics for the respondent of the email (pairs hetero - lesbian)

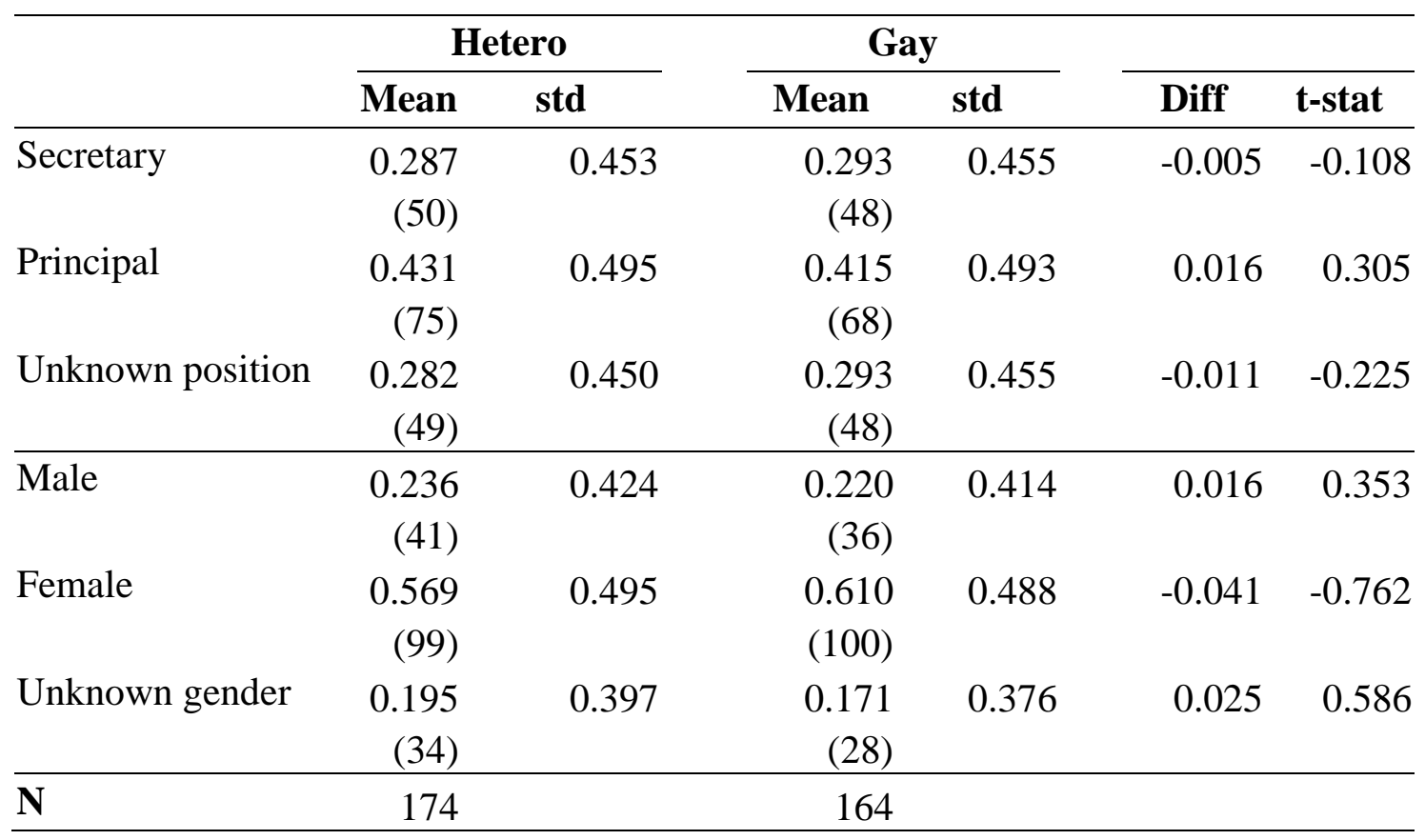

Notes: Number of e-mails within parentheses. 
Table 7: Probit analysis on the determinants of the probability of response and invitation from schools.

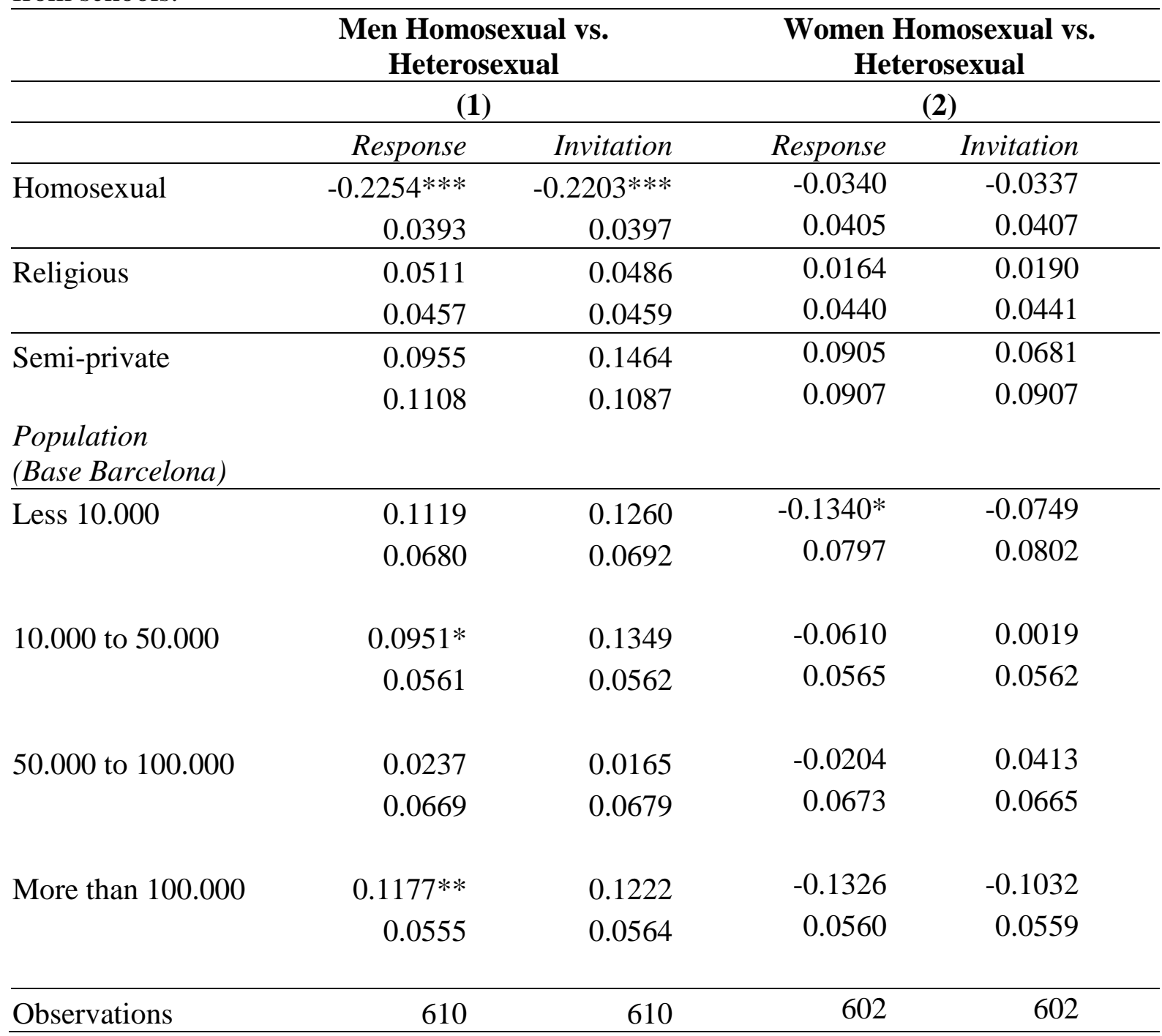


Figure 1: Don't like homosexuals as neighbors

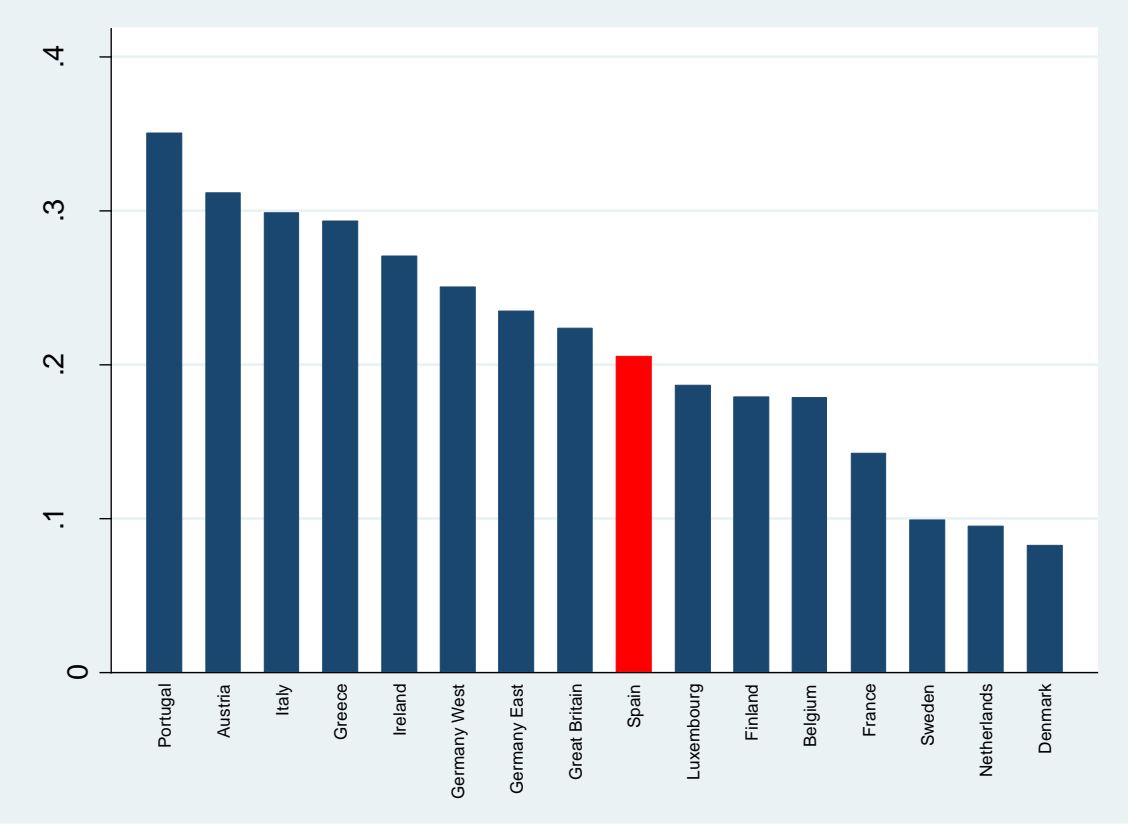

Source: Own elaboration from European Value Study

Figure 2: Children adoption homosexual couples

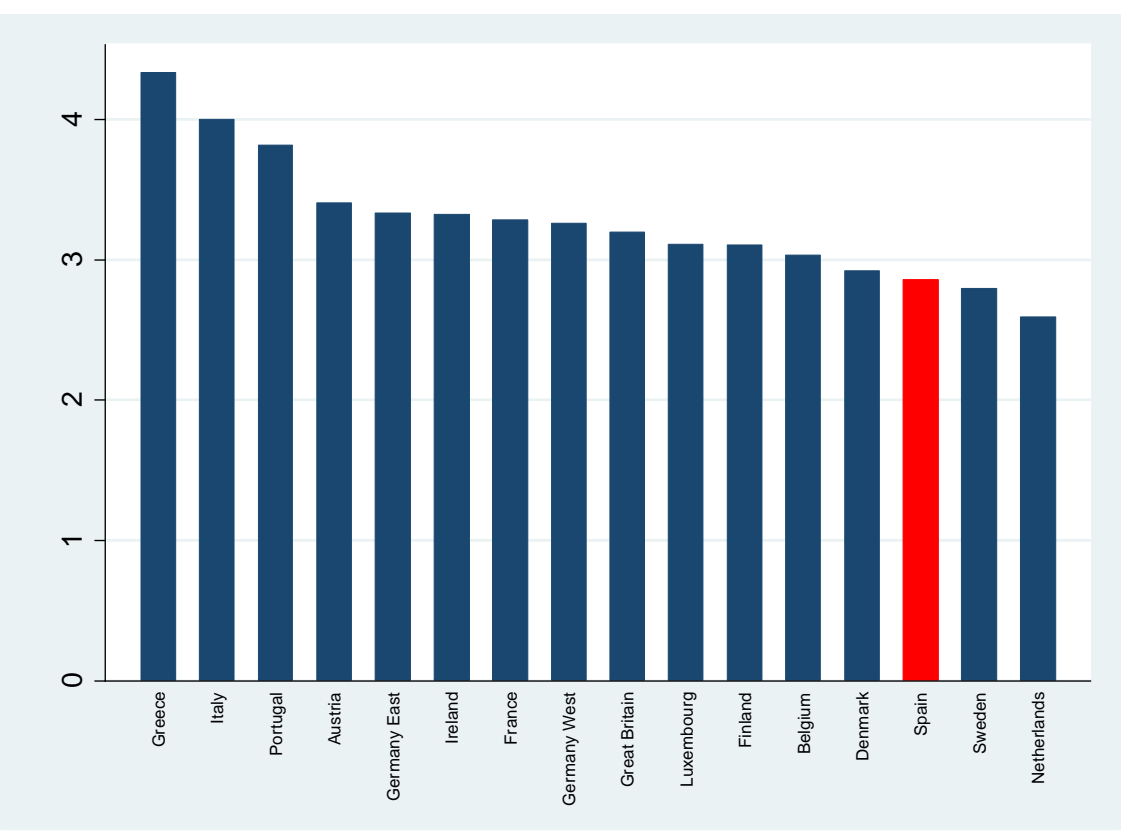

Note: 1 strongly agree; 5 strongly disagree.

Source: Own elaboration from European Value Study 